Voices from the Field: What We Have Learned about Instructional Leadership

$$
\begin{aligned}
& \text { Tony Townsend } \\
& \text { University of Glasgow }
\end{aligned}
$$

Tony.Townsend@glasgow.ac.uk

Michele A. Acker-Hocevar

Washington State University

ackerhoc@tricity.wsu.edu

Julia Ballenger

Texas A\& M University, Commerce

Julia.Ballenger@tamuc.edu

A. William Place

St. Joseph's University

aplace@ sju.edu

Gary Ivory

New Mexico State University

givory@nmsu.edu 
Voices from the Field: What We Have Learned about Instructional Leadership. ${ }^{1}$

\begin{abstract}
This article documents perceptions of superintendents and principals when working under the No Child Left Behind Act (NCLB) in 2004-06. It uses data collected through the Voices 3 Project to consider three factors associated with instructional leadership as applied under NCLB, defining the school's mission, managing the Instructional program and promoting a positive school learning climate. Findings include that the narrowness of the curriculum objectives, the top-down hierarchical nature of decisionmaking in the system, and the pervasively negative and punitive environment impact on the work of instructional leaders. The paper argues that new approaches and leadership models are needed.
\end{abstract}

8638 words plus abstract and references

\footnotetext{
${ }^{1}$ Some of the material in this paper has been adapted from Townsend, T. (2012) 'The Askers and the Tellers: Larger Messages in Acker-Hocevar, M., Ballenger, J., Place, A.W., \& Ivory, G.,(Eds.) Snapshots of School Leadership in the $21^{\text {st }}$ Century: Perils and Promises of Leading for Social Justice, School Improvement, and Democratic Community (The UCEA Voices from the Field Project) Charlotte, NC: Information Age Press
} 


\section{Voices From The Field: What We Have Learned About Instructional Leadership}

There has been concern about the standard of achievement of American students for more than 40 years. From 1971 to 2008, there was a 6\% improvement in scores for reading for 9 yearolds, a 2\% improvement in 13 year-olds, but no improvement in 17-year-olds (NAEP, 2009). There has been some reduction in the gap between advantaged and disadvantaged students in reading at all three levels, but no actual increase over the whole group. The trend figures are similar for both Mathematics and Science. So it could be argued that all the reform efforts that have happened in the U.S. in the last forty years have at best, made some reduction in the achievement gaps between groups of students, especially at the elementary level, but have contributed virtually no increase in overall performance by students by the time they leave school.

There has been a tendency for politicians, media and the community in general to turn their attention to a variety of "problems" in the system and place blame for inadequate school performance on different groups. At one stage the problems were associated with students and families (Coleman et al., 1966; Jencks et al., 1972), but with the advent of the school effectiveness research from the 1970s (see Weber, 1971; Edmonds, 1979), with the principle that "all students can learn," blame has been reapportioned variously to, teachers, teacher education, principals and leadership education. Teachers and administrators have become progressively more accountable, more watched and more sanctioned, as time has progressed. The last decade of this period has been overseen by a national policy framework identified by No Child Left Behind (2002) and much of the leadership of schools within this period has been aligned with the leadership practices associated with Instructional Leadership (Hallinger \& Murphy, 1985). 
The purpose of this article is to consider how three factors associated with instructional leadership, defining the school's mission, managing the instructional program and promoting a positive school learning climate, are perceived by instructional leaders within the framework of the national No Child Left Behind policy. To do this we consider qualitative data collected over a three year period from focus group meetings of school superintendents and principals during 2004 and 2006.

The Voices from the Field: Phase 3 (Voices 3) research is the third stage of a University Council for Educational Administration (UCEA) project that began in the mid-1990s. Taylor and Touchton (2005, p. 13) reported that the "two previous studies, Voices Phase 1 (Kochan, Jackson, \& Duke, 1999) and Voices Phase 2 (DiPaola, Acker-Hocevar, Grogan, Davis, \& Ivory 2002), addressed principals' and superintendents' most vexing problems and challenges, and preparation, expectations and challenges respectively." Voices 3 targeted the interviews at principals' and superintendents' perspectives on school improvement, social justice, and democratic community (Murphy, 2002). One question specifically asked, "What has No Child Left Behind meant for you as a leader in education?" This article focuses on the views of principals and superintendents and makes use of all the transcripts of focus groups, not merely the responses to this question.

UCEA researchers conducted 13 principal focus groups, stratified by type of school (elementary, middle, high) and region of the U.S. in which the school was sited (New England \& Mid-Atlantic, Midwest, Southeast, and Southwest \& West) and 14 superintendent focus groups, stratified by, on the one hand, the size of the student population in the school district (small, medium-sized, or large), and on the other, by region. In total 81 superintendents and 85 principals shared their views. All groups discussed all three topics, a design motivated by Gross 
and Shapiro (2005), who argued it is difficult to tease out school improvement, social justice, and democratic community as separate constructs because the three seem interdependent with each other.

The transcriptions from each of the focus group meetings removed any identifiers of individuals, schools, districts or states, and standardized punctuation conventions. We used what was said by leaders to establish a better understanding of the overall educational environment in which they worked. Acker-Hocevar et al. (2012, p. xi) described how they presented demographic information:

We identify by number the superintendent or principal speaking, but we provide demographic information (size of district or level of school, region of the country represented, and year the focus group took place) only on the focus group as a whole. For example, though we tried to restrict each superintendent focus group to districts of similar size, on occasion a superintendent from a different-sized district participated. In such cases, the superintendent is identified by number along with the characteristics of the focus group, (e.g., superintendent 31, mixed medium-sized and small districts, Southwest and West, 2005).

Data collected in the focus groups of the Voices 3 research project will be used to address each question of two research questions:

1. What is the impact of secondary NCLB's goal, to create and implement an assessment regime with significant consequences, on district and school leadership?

2. How are the three factors associated with instructional leadership, defining the school's mission, managing the instructional program and promoting a positive school learning climate, applied under the provisions of NCLB? 
To understand the current position of education within the U.S., it is important to set the policy and leadership framework in which schools are operating. For the policy framework we will consider the role of aspects of No Child Left Behind (NCLB, 2002), a law intended to establish a policy environment that would lead to rapid and substantial improvements in student achievement, as measured by standardized tests in the areas of reading, mathematics and science. For the leadership framework, we will consider the theory and practice of instructional leadership (Hallinger \& Murphy, 1985, the dominant school leadership terminology in the U.S. for the past quarter of a century). Importantly, we will consider the elements of instructional leadership using data collected from the Voices 3 research and how they have been used to respond to NCLB.

\section{The Policy Framework: No Child Left Behind}

The No Child Left Behind Act of 2001, and subsequent law of 2002, aimed to create the policy framework that would enable American students to achieve at high levels in school. Kew et al. (2012) argued that "NCLB is comprised of four pillars: "stronger accountability for results," "more freedom for states and communities," "proven education methods," and "more choices for parents" (p. 13).

The federal No Child Left Behind (NCLB) Act of 2001 aims "to bring all students up to the proficient level on state tests by the 2013-2014 school year, and to hold states and schools more accountable for results" (Great Schools, 2012, para. 1). NCLB was based on a sound set of principles. It was positive in "changing mindsets of what leaders expected in the classroom and altering how teachers taught students with varying needs" (Murakami-Ramalho \& Rodríquez, 2012, p. 57) and it "brought more focus to curriculum and instruction and held principals and teachers more accountable" (Alsbury \& Whitaker, 2012, p. 173). However, NCLB has produced 
meager gains in achievement. The National Assessment of Educational Progress (NAEP) assesses student achievement in reading and mathematics every other year. Despite the intense concentration on reading and mathematics required by the law, the gains registered on NAEP since the enactment of NCLB have been unimpressive (Ravitch \& Chubb, 2009). For example, The Nation's Report Card (NAEP, 2009) indicated that only 33\% of fourth-graders and 32\% of eighth-graders are proficient in reading, slightly up for grade 8 from 2007, but just the same for grade 4 . With mathematics, $39 \%$ of fourth-graders and $34 \%$ of eighth-graders were proficient, slightly up for grade 8 , but just the same for grade 4, and for science, $34 \%$ of fourth-graders and $30 \%$ of eighth-graders were proficient, but these performance percentages could not be compared to 2007 because of changes to the assessment. With barely one-third of fourth graders being rated as proficient, the data indicated that the U.S. is not appreciably closer to the NCLB goal of having all students reach the level of "proficient" on state assessments in reading and mathematics by 2014. As the Census data for 2010 (U.S. Census Bureau, 2012) reveals that there are approximately 49 million elementary and secondary students in the United States, if these percentages are the same for all students, then nearly 33 million students are struggling for proficiency in all three areas.

Peterson and West (2003) argued that the first goal, to close the achievement gap, was not the only goal of NCLB. There was a secondary goal, to create and implement an assessment regime with significant consequences, by holding schools and school systems accountable for those who fail. Darling-Hammond and Rustique-Forrester (2005) argued "The central assumption of this major federal bill and of many state accountability schemes is that by holding students, teachers, schools, and districts responsible for results on standardized achievement tests, expectations for students will rise, teaching will improve, and learning will increase" (p. 
289). It seems clear that this goal has been achieved to a greater extent than the first one; there is now an accountability system in every state, one that seems to focus on blame and failure. What this has done, over time, is to create a great deal of pressure felt by many people in education.

\section{Four State's Assessment Systems}

The current study considered the views of superintendents and principals in four different regions of the U.S., New England and the Mid-Atlantic, Midwest, Southeast, and Southwest and the West. NCLB impacted on all of these regions and it may be instructive to look at what testing systems were in place to comply with the act. We have selected four states, the largest in each region, based on school population, Florida, California, New York and Texas, to do this.

Accountability in Florida is known as the Florida Comprehensive Assessment Test (FCAT) "which measures student success with the Sunshine State Standards, will include assessments in reading, mathematics, and writing (grades 4, 8, and 10) in the 2011-2012 school year. Historically, the FCAT measured the Sunshine State Standards in reading and mathematics (grades 3-10), science (grades 5, 8, and 11), and writing (grades 4, 8, and 10)" (FLDOE, 2012a, para. 4).

In California, school students undertake the Standardized Testing and Reporting (STAR) tests each year. "Each spring, students in grades two through eleven take a STAR test. The STAR Program looks at how well schools and students are performing. Students take tests in math, reading, writing, science, and history" (California DoE, 2012).

The state tests given in New York are standardized tests "developed by experts and must be given to students at the same time in the same way. They are tests that measure what a student knows compared with other students at the same grade level. New York gives students tests in: 
English Language Arts (ELA), Math, Science, and Social Studies” (Parental Information and Resource Center, 2012, para. 1).

In Texas, from 1981 to 1990 , as required by state statute, minimum skills in reading, mathematics, and writing were assessed. In 1990 the Texas Assessment of Academic Skills (TAAS), shifted the focus of assessment from minimum skills to academic skills and in the 2002-2003 school-year, the Texas Assessment of Knowledge and Skills (TAKS) replaced TAAS as the primary statewide assessment program. TAKS is designed by legislative mandate to be more comprehensive than its predecessors and measures more of the state-mandated curriculum (Texas Education Agency, 2009).

A sample practice test for grade 10 Reading for the Florida FCAT indicates that reading ability is tested by asking students to read a paragraph and then to answer a series of questions, each of which involves them choosing the right answer from one of four choices. Although in previous years there were questions that were identified as "read, think, explain" questions, there is now a statement that that notes that "Performance Questions (Read, Think, Explain questions) are no longer on the FCAT (FLDOE, 2012b). Similar tests can be found for reading in California (CBEST, 2012), in Texas (Pearson, 2012), and New York (NYSED, 2012)

One could be forgiven for believing that the common school curriculum across the most populated states was reading, writing, mathematics and science, as these are the only four areas tested in every state. These are also areas mandated by NCLB. One also could be forgiven for thinking that the nature of testing itself lends to teaching and learning becoming a process of applying specific skills of test-taking, finding the answers in material supplied, or remembering the answer. There appears to be no test of analysis, or decision making, just remembering, or being able to find, the answer within the paragraph studied. 
However, it was not so much the standardized testing program itself that was creating pressure for educators, but the consequences attached to the results from them.

NCLB requires all districts and schools receiving Title I funds to meet state "adequate yearly progress" (AYP) goals for their total student populations and for specified demographic subgroups, including major ethnic/racial groups, economically disadvantaged students, limited English proficient (LEP) students, and students with disabilities. If these schools fail to meet AYP goals for two or more years, they are classified as schools "in need of improvement" and face consequences. (Great Schools, 2012, para. 1)

States responded to these requirements in different ways. Florida, for instance, was identified by Winerip (2012, para 20) as having one of the toughest accountability systems in the country.

Former Gov. Jeb Bush, who was in office from 1999 to 2007, put into effect what may be the most aggressive testing system in the country, and subsequent administrations have followed his lead. Test scores are used to determine which third graders must be retained and which high school students can graduate. They determine a school's report card grade, from $\mathrm{A}$ to $\mathrm{F}$, as well as which teachers and principals will get bonuses and which ones will be fired.

Palmer and Lynch (2008) provided a description of what the Texas approach entailed:

Texas third and fifth grade teachers must contend with another major policy imposition: the Texas Assessment of Knowledge and Skills (TAKS), which is administered annually to students in third through eighth grades. In the elementary grades 3-5, students all take the TAKS reading and math tests. In fourth grade they also take the writing test, and in 
fifth grade they take the science test. TAKS tests carry high stakes at the federal, state, and local levels. They are used to rank and assign ratings to schools statewide, a system that carries consequences for poor performance including eventual state takeover (p. 219).

Such draconian measures identified in policy statements resulted in changed teacher practice. Madden (2008, abstract), in a study that considered middle school teachers' perspectives of the implementation of the FCAT science test in Florida found that:

Results of the study indicated that FCAT Science has affected the teaching practices of the science teachers by changing the depth and scope of their teaching. Teaching methods had shifted into more traditional methods of delivery with less inquiry-based learning and less hands-on labs. Teachers reported that they taught test-taking strategies. Loss of autonomy, increased job stress, and lack of time to teach in-depth were commonly voiced by educators.

Fuller (2008), in his study considering the perceptions of 500 teachers and 500 parents about the TAKS test in Texas, found that neither group was opposed to accountability, but the extent to which testing and accountability had been taken:

...the results suggest that many teachers and parents have mixed feelings about the TAKS, thus reflecting their perceptions that the TAKS has both positive and negative impacts on students, teachers, and the quality of education in Texas. Importantly, the results suggested that neither teachers nor parents want to return to the days of no assessment or accountability. Indeed, both teachers and parents suggested that the system has simply swung too far from one extreme (no testing or accountability) to another (too much testing and accountability) (p. 3). 
A similar response occurred at a national level. Abrams et al., (2003) in a national study of teachers who responded to questions about the impact of NCLB, found that educators felt intense pressure to raise test scores, and to do this they taught in ways that they felt were not sound practice. They also found that teachers felt state tests had more influence on curriculum and instruction than did national content and that this led to a focus on those aspects of the curriculum being tested, which led to sacrificing both non-tested content and enrichment activities.

It is important to understand that NCLB is a federal law in a country where states have the responsibility for delivering education to the population and have created state assessment tests to assess student outcomes. So why would such a law be attractive to states? Bill Gates in his TED Network (http://www.ted.com/) talk called "How state budgets are breaking US schools" (Gates, 2011), provides us with a reason. He provides evidence that federal, state and local budgets make up $36 \%$ of the U.S. 2010 GDP of 14.7 trillion dollars, but that currently there is a deficit of $10 \%$ between revenues and expenditures in government budgets and this has been getting progressively worse since 2001-02. He cites California as an example of a state facing a budget shortfall of nearly 33\% (\$25 billion deficit in a \$76 billion budget), one that has been increasing since 2000. He also reports that projected expenditure on health care will increase from $26 \%$ of the Californian budget in 2010 to $42 \%$ in 2040 . He argues with both budget deficits and an increasing health care bill, the state level money available to fund schools is getting more limited by the year. Thus, NCLB, being federally funded, may have been seen as a financial lifeline by states, despite the rigid conditions that came with it.

This is the policy context in which superintendents and principals responded to the questions posed by the Voices 3 research in the years between 2004 and 2006. It was a context in 
which the expectations of student achievement for the basic school skills was heightened substantially, one where students who may have been previously ignored were now considered in school performance measures and one where there were significant consequences for districts, schools, school leaders and teachers if improvement did not occur. This context is important because it helps to understand the way in which schools have had to shape their work, and are judged, and it connects to school leadership because increasingly, school leaders are being held responsible for the level of performance of their school within this framework.

\section{The Theoretical Construct: Instructional Leadership}

The emergence of the term instructional leadership dates from around the mid-1980s (Chase \& Kane, 1983) and three dimensions of this role, with 11 leadership tasks, were proposed (Hallinger \& Murphy, 1985): Defining the School's Mission (which included framing and communicating school goals), Managing the Instructional Program (which included supervising and evaluating instruction, coordinating curriculum and monitoring student progress), and Promoting a Positive School Learning Climate (which included protecting instructional time, promoting professional development, maintaining high visibility, providing incentives for teachers, enforcing academic standards and providing incentives for students). This view of leadership is essentially hierarchical and managerial and lends itself to the view that the school leader is the single person to oversee local implementation of decisions designed to maximize student learning and to improve the school in doing so.

Defining the school's mission identifies the focus of schooling, managing the instructional program relates to the nature of decision making and relationships, and promoting a positive school learning climate considers the environment in which schooling occurs. These factors can be considered the basic elements of learning, the curriculum we deliver, how we 
deliver it and the conditions surrounding the learning activity. These three factors also operate in the adult world as well, and most human transactions include a task, relationships between the people involved and outcomes that follow completion of the task. So mission, management and climate operate in the classroom, the school, the district, and even at the policy level, where politicians and state or district administrators interact.

Although the early U.S. research into instructional leadership adopted what might be considered a direct effects model, where the assumption was that leadership had a direct effect on student performance, in recent times a more comprehensive view of how leadership and student achievement interacts has been explored. In a recent article Hallinger and Heck (2011) considered four different models of how leadership might impact on student achievement in their study of 192 schools in a single state in the U.S. The results of this study suggested that the hierarchical direct effects model, although it may have been attractive initially, did not generate the results underpinned by Hallinger and Murphy's initial 11 leadership tasks from 1985. The recent research instead found a much more complex relationship between leadership, especially collaborative leadership, and learning: “...the overall pattern of results favored a perspective on school improvement leadership as a mutual influence or reciprocal process" (Hallinger \& Heck, 2011, p. 479).

There is also evidence that the task of leading a school is now too large for a single person. As Gronn (2003) argued,

Leaders' work has now become greedy work - greedy work performed on behalf of greedy organisations in pursuit of voracious and stingy public policies" and where "workaholism is fast becoming the grammar or culturally accepted norm of the new work 
order..." where work "...has to become an end in itself, rather than a means to an end..." and where "One lives to work, rather than works to live" (p. 153).

If we add rapid change to a continually increasing workload, then the position of a single "heroic" leader becomes virtually untenable.

However, there still seems to be a "romance" with the idea of the power of leadership that leads us to believe that the leadership role is more important to student achievement than anything else. Such a position is perhaps best shown by the Barber et al., (2010) statement, "[There have been] ... a large number of quantitative studies in North America which show that school leadership influences performances more than any other variable except socio-economic background and the quality of teaching" (p. 5). Further, a study identified but not named by Barber et al., (2010) concluded that, "nearly 60 per cent of a school's impact on student achievement is attributable to principal and teacher effectiveness. This statement may even understate the potential impact of effective school leadership, because leadership is itself one of the main drivers of the quality of teaching" (p. 5).

The assertions above are a rather slippery use of language in a number of ways. First, it identifies, but ignores, the two other factors identified as being more important than leadership, the student on the one hand and the teacher on the other; second, it then talks just about the "school's impact," ignoring the huge effect of student, home and community; and third, it puts teacher effects and leader effects together to suggest the absolute importance of these two factors together. Hattie's (2008) meta-analysis of a substantial body of research argued that around 50\% of the variation in student achievement can be tracked back to the student, around $30 \%$ of the variation comes from what teachers do and only about $5 \%$ can be attributed to what school leaders do. So what Barber et al. (2010) has said is true, but misleading. Yes, "school leadership 
influences performances more than any other variable except socio-economic background and the quality of teaching," but it is still only 5\%; and yes, "60 per cent of a school's impact on student achievement is attributable to principal and teacher effectiveness," but $55 \%$ of the $60 \%$ comes from the teacher.

However, the current article uses data collected through the Voices 3 Project from 20042006, when the direct effects model of instructional leadership was still generally supported, to consider how the three factors associated with instructional leadership, defining the school's mission, managing the instructional program and promoting a positive school learning climate, are perceived by instructional leaders within the framework of the national No Child Left Behind Policy.

\section{Results}

\section{The Impact of NCLB on the Lives of School Leaders}

It is clear that NCLB in itself has had a range of positive outcomes and these have been identified by both superintendents and principals in the Voices 3 data. First, it has provided a focus and an impetus for data-driven school improvement. As one principal indicated "[NCLB] in some ways, it has made life simpler as a leader because you can look at your staff and say..., 'No choice; it's in there; gotta do it'” (Principal 81, high school, Midwest, 2006). Another argued "I think with AYP and our need to drill down a bit, I feel that I've become much more astute at using data... considering data... I think it was beneficial for that..." (Principal 71, middle school, Midwest, 2006). School leaders acknowledged the positive impact of NCLB on their day-to-day practice. "NCLB is about accountability and focus. It is not necessarily bad... I think it aided administrators in painting a picture in how to move forward" (Superintendent 48, medium-sized and small-sized districts, Southwest and West, 2004). 
NCLB also made it clear that it wasn't just the average performance of a school that would count, but sub-groups all had to perform. Again, this was something that was seen as positive. "We can't ignore the African American subgroups or the special education population or any other minority populations. It is always good to look at how kids are achieving, and 'What can we do better?' I think in that aspect it is very good." (Principal 66, middle school, Midwest, 2005) and "You can't not educate one group of kids" (sic) (Superintendent 68, medium-sized districts Southwest and West, 2006).

On the other hand, principals voiced their concerns about the pressures of high-stakes testing and AYP mandates.

There are so many people in the community, board members, and even high school people don't get it. Now the pressure is coming from them, too. They haven't had the same pressure as we've had to deal with in elementary with No Child Left Behind. They haven't had to try to raise test scores. It's so hard when you are dealing with people who have no understanding of all you really have accomplished. (Principal 1, elementary school, Midwest, 2005)

There were external pressures as well.

The pressures of the outside forces, standards and all those things... It's not that I don't believe in them, but I see what the teachers are trying to do on a daily basis, and I know that the pressure to move on to get to the end of course exam or get the kids ready. I see teachers frustrated... (Principal 33, elementary school, Southwest, 2006)

and

I am a Title 1 school, I-about $86 \%$ are reduced lunch. Our challenges are massive, and if you succumb to the pressure, the AYP pressure, and all the other stuff that goes along 
with this-you [are] going to do a disservice to the school. (Principal 50, elementary school. Southwest and West, 2006)

Likewise, superintendents voiced their frustration with the pressures exerted by the NCLB mandates. "Could we have done it without the pressure? Yes, we sure could have". (Superintendent 35, small-sized sistricts, Midwest, 2004). Part of the concern identified is the unrealistic expectations placed on the school system.

We're going to have $100 \%$ graduation rate by the year 2014. Under the standard that they currently have in place that establishes what composes $100 \%$ graduation rate, I maintain it is humanly impossible to do that because there's factors totally beyond our control that we simply cannot do...It won't happen; there's no way. All it takes is one little factor to bounce in there that causes kids to shift, or move, or something. (Superintendent 26, medium-sized districts, Southeast, 2005)

These pressures are seen as one of the reasons that it is difficult to find, and then keep, talented teachers.

The stakes are so high now that we have to be risk takers...I think somebody's got to stand up and take care of the kids and just as importantly, the staff, who is taking care of the kids, because I think the real risk that we have right now in public education is the pressures on our teachers, our classroom teachers, and the fact, it's going to be hard to keep the ones we have and even harder to replace them. (Principal 75, high school, Midwest, 2005)

Even if teachers stay, a further concern is that their practices might change as they focus only on a narrow range of outcomes: 
...they have taken those problems and they have painted the whole country with one brush and said that same set of situations exists everywhere. That ain't the way it is. And it is unfair and it is hurting good districts and good kids in the process... when you get to that point where districts start getting identified, and the pressure begins to come in from people who don't know any better, then you are going to see people start doing things that normally good educators would not do. And that doesn't scare me, it angers me, that people would be forced to make those decisions... (Superintendent 35, smallsizeddistricts, Midwest, 2004)

Fullan (2005, p. 175) called for "accountability and capacity building, or what used to be called pressure and support" in order to undertake turnaround leadership, but what seems to be happening instead under NCLB is that "the mantra 'pressure and support'... recently has come to mean 'pressure"' (Little, 2012, para 16). If the pressure side continues to build, with little capacity building included, then the system is likely to break. Perhaps messages can be taken from other places. Elmore (2007), in his review of the Victorian (Australia) approach to leadership development argued we need first to trust in the people we have asked to do the job:

From the ministerial level, through the department level, to the operating level of the public schools office, into the regions and then into the schools, there is broad agreement on the essential message that the strategy is fundamentally about investing in the knowledge and skill of people (p. 2).

For NCLB to become successful, it needs to review how it treats, and invests, in the people it has charged with delivering the very challenging goals it asked for. In the next section, our review of the three factors associated with instructional leadership may assist us to see how that might be happening. 


\section{Instructional Leadership under NCLB}

When the data from the Voices 3 project were being collected, the direct model of instructional leadership still seemed to be the one considered most likely to evoke changes in student performance. Both principals and superintendents referred to this type of leadership in schools where the school leader was seen as being "the" instructional leader. For principals, the role was quite clear, they construct the vision of the school: "I'm going to be the leader of the vision and I'm the instructional leader and I know that those are two of my primary goals" (Principal 4, elementary school, Midwest, 2005), and "I wrote that I have to educate and convince all the stakeholders that the vision that I have as the hired instructional leader is the right vision which affects almost every decision that I make" (Principal 33, elementary school, Southwest, 2006).

It is also clear that the approach taken is a hierarchical one: "You talk about instructional leadership, I think the key is that it all starts at the top and fosters on down" (Principal 9, elementary school, Midwest, 2004) but that this sometimes causes problems between principals and teachers “... (it is) my perception that they are not willing as a whole to grow and are not open to me being their educational leader or their instructional leader" (Principal 64, middle school, Midwest, 2005).

Superintendents see their job, in part, as making sure that principals become instructional leaders, even if “it's pretty tough as an instructional leader to get up and tell everybody that they will clear that bar..." but “... making instructional leaders out of my principals and my administrators..." (unnumbered Superintendent, medium sized districts, Southwest and West, date unknown) is a core activity for them. 
The statements mentioned above suggest that school leaders saw themselves in a hierarchical relationship with those below them, it was their responsibility to establish conditions where students will learn, and that this would directly affect student outcomes. It could be argued that NCLB demonstrated the same understanding, namely, that something conceived at the national level could have a direct effect on student achievement. As we have seen above, this has not come to pass.

\section{Defining the School's Mission (Curriculum)}

The school leaders in the Voices 3 project provided numerous references that testified to the curriculum narrowness of what is being delivered currently to American students: "We end up in small school divisions focusing such an inordinate amount of our resources, our time and money, on meeting those standards that we have so many other things that get left in the dust" (Superintendent 17, small-sized districts, Southeast, 2006) and "We're spending about 100\% of our time in demonstrating test score proficiency on NCLB and we're graduating a senior with about $75 \%$ of what they need to know in the real world" (Principal 80, high school, Midwest, 2005).

The opportunities for teachers to make professional decisions about what and when things might be taught have also been narrowed: "I think the freedom to teach whatever the teacher feels is important to them has really narrowed down... We have to teach these standards and benchmarks, but teachers feel like their teaching spectrum has really closed up..." (Principal 15, elementary school, Southwest and West, 2005) and “It's just all tasks. There's no creativity, and when you stifle someone's creativity, [teachers] don't want to do that" (Superintendent 18, Medium-sized district Southwest and West, 2005). One superintendent argued “... how can you 
take one value system and force it on everybody and say - This is best?" (unnumbered Superintendent, medium-sized districts, Southwest and West, date unknown).

But are teachers concerned about having the right to make curriculum decisions, or are they concerned that the curriculum as it is currently identified is not being taught? It seems that teachers don't want less accountability (Fuller, 2008), but that the current accountability balance goes too far. Schools are expected to deliver a broad curriculum, but only some of it is considered "high-stakes." Leaders seem not to be asking for anything and everything to be under teacher control, but that more than the bare minimum identified by NCLB be considered as important. The British work on personalized learning (Hargreaves, 2009) or deep learning (Hargreaves, 2003) or the Canadian work on teaching for deep understanding (Leithwood et al., 2006), both of which argue for a more comprehensive approach to learning, may be the answer.

This leads to a secondary issue with the curriculum, namely the high-stakes nature of the tests, which has led to a narrowness of the judgments being made, with success determined by a single test on a single day of the year: "yes it's reasonable to be accountable and it's reasonable to have standards, it's reasonable to be tested on those standards. But, what are the stakes? And is one test in a week in March, is that fair?" (Principal 59, elementary school, Midwest, 2005) Such a position does not seem to resonate with the reality of many students lives:

For me it's a lofty ideal that these people sitting over in Washington, D.C. come into a classroom, come into a building and see the children that go home and have no one at home; have no food at home. The least of their worries is whether they're going to pass that [state standardized] test come February. (Principal 10, elementary school, Midwest, 2004) 
This pressure to succeed again demonstrates the level of concern about the nature and breadth of the curriculum being offered. For some, the focus of what the purpose of school should be has changed:

I'm really worried that it (AYP) has changed our focus and maybe forced us to not realize what we do in a school. If we think that all we do is grade test scores and everything can be measured. There's a phrase that I use often: "Not everything that's important can be measured. And not everything that can be measured is important." (Superintendent 74, medium-sized districts, Midwest, 2005)

It is clear from the quotes that the perception held of NCLB by both superintendents and principals is that it tries to focus the attention of everyone on a very narrow range of curriculum outcomes and this is seen to be the case for both superintendents and school principals. It seems the mission of the modern American school has narrowed substantially in the past decade under NCLB. By focusing on basic skills and measuring these through standardized tests, learning seems to be about individual facts, tasks, or bits of information, and getting these things right when tested. Much of the success of schools is judged by the ability of students to be able to choose which of four answers to the prompt question is correct rather than (for example) by the ability of students to be able to articulate a position on any given topic, to consider how different varieties of background information might inform a decision, to recognize weaknesses in arguments (including their own), or even to work their way through choices when there are more than four, or more than one that might be defensible. Remembering right answers is seen as more important than having opinions. Responses here support the view of Abrams et al.'s (2003) study that there is perceived pressure to focus attention on a very specific set of skills. Perhaps it is this 
pressure that currently prevents some schools, those that struggle to meet NCLB requirements, to even consider approaches such as teaching for deep understanding (Leithwood et al., 2006)

Are there other human skills that are currently being ignored but might be more important to an increasingly diverse range of school students as they grow towards adulthood? The current narrowness of content implies that a single set of experiences is equally valuable for all students, despite the fact that the diversity of the population of schools in the U.S. is now equal to or greater than the diversity that exists anywhere else in the world. Perhaps it is this minimalist focus that contributes to failure, as only those who succeed in this narrow range of tests are seen to be evidence of school effectiveness.

Leadership in this sense also becomes narrowly focused, designed to maximize student achievement on a limited range of standardized tests and placing pressure on teachers for this to happen. The leaders in the Voices 3 project consistently expressed their concerns about the narrowness of the expectations now facing schools and the ways in which they were judged.

\section{Managing the Instructional Program (Pedagogy and Relationships)}

The second issue to consider under NCLB policy and instructional leadership practice relates to the way in which people interact with each other. People from government seem to spend a great deal of time telling teachers and school leaders what they should do, despite the fact that they have no background in teaching and no real understanding of children's learning. This is seen by some as being political interference and is something that some educators resent: "I think the NCLB should make every politician spend one week in an urban school classroom by themselves and I think they would change their whole concept of what they're making laws for" (Principal 57, elementary school, Midwest, 2005) and "I think the notion that everybody wants to have more say in the decision, at least from my perspective with the school that I am 
principal of, is that it's coming from the politicians, that it's not coming from the parents in our community" (Principal 45, elementary school, Southwest, 2006).

By offering additional funding through NCLB, but by tying this funding to very specific outcomes, the Federal government tells states what they have to do to get this much needed money. The states tell districts, school boards tell superintendents and they tell schools what has to happen. School leaders then have to implement some quite specific activities within classrooms to ensure that the school continues to receive the funding they need to survive. The people most responsible for the learning outcomes of the U.S. education system (the students) and the person most likely to guide, encourage and teach them (the teacher) are, ironically, the least powerful people in this chain.

U.S. education seems to be moving further and further away from "local control of education." Randall Clinch (2001) argued, "There are two types of teachers: The askers and the tellers," and he suggested that it is in those classrooms where most of the time teachers use questioning and explaining as a mechanism for getting the message across, that learning really happens. However, under NCLB, a top down, "telling" form of decision making occurs at all levels, and NCLB argues there is more choice provided, but ultimately there is none. This is supported by the data from Voices 3: “...there are too many things that I may spend a couple of meetings trying to get you to buy into it, and then I'm going to tell you that that's the way it's going to be" (Principal 20, elementary school, Southeast, 2005) and "You cannot argue against it, but the devil is in the details. Is NCLB coercion or best practice? I don't have a problem with the concept, but it is being forced down our throats" (Superintendent 47, medium-sized and small-sized districts, Southwest and West, 2005). 
Even when there is encouragement for people to voice their opinions, final decisions at district level are made by leaders: "And so, I think their voice is important, but the decision doesn't reside there. The decision resides with me. And so, voice is important, but it's not the decision-you know, this is not a democratic decision" (Superintendent 68, medium-sized districts, Southwest, 2006), which is also recognised as an issue by principals “...in our district there is almost an absence of principal dialogue in decision making" (Principal 51, elementary school, Southeast, 2006). However, principals also use this form of decision making themselves: "Once in a while I'll come back from an administrators meeting and say - OK, this is a topdown decision, we have no say in this, this is the way it's going to be and you have to accept it" (Principal 10, elementary school, Midwest, 2004). In this sense, the current study supports the findings of Palmer and Lynch (2008) that many people feel that they are being imposed upon and Fuller's (2008) study that found that although people accepted accountability and did not want to return to previous approaches, nevertheless the current measures have gone too far to be productive.

People do not like to be told what to do, to be given little or no option about their own practice, especially when they consider themselves to be professionals, highly educated people with specialized skills to do a particular task. We see the dilemma faced by the instructional leaders in the project when confronted by the task of doing the 'right thing by students' but finding themselves constrained by the rules handed down: "We rarely mention No Child Left Behind in our meetings with staff. We are doing what we are doing because it is the right thing to do for students" (Superintendent 38, small-sized districts, Midwest, 2004), sometimes even going as far as to break them “...if I have a unique situation, and I think it's in the best interest of their kids and their learning, I break the rules" (Principal 83, high school, Midwest, 2006). 


\section{Promoting a Positive School Learning Climate (Environment)}

The third factor associated with instructional leadership is the environment in which the activity of schooling takes place. If we as a society do not trust educators, can we really conceive of a credible way of improving education? The lack of trust exhibited for educators to make decisions within the framework of NCLB is demonstrated by some of the Voices 3 quotes below. School leaders don't think that they are trusted, even by the people who employ them, “...they just feel like nobody trusts them. You have got to work to build that... not that he (the Superintendent) doesn't hire good people. He doesn't trust them to do the work" (Principal 33, elementary school, Southwest, 2006), which leads to a lack of self-confidence in what they do: “It's (NCLB) a lack of trust for our profession like we haven't been doing what we are supposed to be doing" (Principal 38, elementary school, Southwest, 2005).

Much of the blame for the current environment, where teachers and school leaders feel that they are not trusted, is placed at the feet of politicians and policy makers, "...there is a generalized lack of trust in school today. Is this the position that has been perpetuated by our legislators?" (Principal 40, elementary school, Southwest, 2005), to the point where some feel that this has been a deliberate attack on public education. "I think it's (NCLB) set up to make public schools fail. I think that's the goal of it. I think that's always been the goal of it (Superintendent 4, mostly small-sized districts, Midwest, 2006).

It is apparent from the statements made by the Voices 3 participants that although NCLB has some good features from a policy point of view, such as a focus on all groups of students as a means of increasing the accountability of schools, the implementation of the policy has led to a narrowing of the curriculum due to the high stakes testing, a hierarchical, "telling" means of transmitting information, and a punitive and fearful environment in which to work. Instructional 
Leadership under these circumstances has not been able to generate the level of improvement required.

\section{Discussion}

The data from the Voices 3 project leads to five findings. The first finding is that both superintendents and principals use the terminology of instructional leadership when referring to their practice as school leaders. Principals see themselves as instructional leaders and superintendents see themselves as people who foster instructional leadership. However, this may be a contributing factor to some of the problems faced by U.S. education today. Instructional leadership seems to "support growth with a focus on results" (Pedwell et al., 2011, p. 613) where "much of the instructional leadership literature reduces learning to 'outcomes"” (MacBeath \& Townsend, 2011, p. 1250). It ignores the fact that education and learning, at their roots, are about people. Elmore argues (2003) that this leads to problems of both implementation and resourcing. [In] ... state accountability systems in the U.S. and the U.S. national policy (No Child Left Behind), accountability for performance is considered to be the leading instrument of policy and human investment is considered to be a collateral responsibility of states and localities, which can be exercised according to their preference. In the U.S... this situation has resulted in a disastrous gap between capacity and performance - the states and the federal government exert increasing pressure on schools to perform, but have essentially defaulted on their responsibility for human investment, leading to an increasingly large number of low-performing schools that continue to operate at low capacity (p. 2).

As we pointed out earlier, there is now plenty of "pressure," but there doesn't seem to be much "support." Instructional leadership, with its hierarchical approach, where the leader is the 
key person in the enterprise, and simply directs others to follow his/her vision of what the school should be, exacerbates an already top-down strategy. Since the vision is most likely created by someone else in the first place, and is likely to only focus on student achievement in a narrow way as well, it is a limited and limiting view of the power of education. We are confirming previous research that having an accountability system that goes too far (Fuller, 2008) and is punitive in nature (Winerip, 2012) leads to focus (Abrams et al., 2003), but also pressure (Abrams et al., 2003). As we know, too much pressure eventually leads any system towards a breaking point.

The second finding is that although NCLB has introduced urgency for school leaders to support teachers in understanding factors impacting on student achievement and improving their ability to use data to support changes in student performance, it does not seem to have provided the resources for leaders at the school or district necessary for them to do so. What has happened is that school leaders KNOW so much more than they did in 2000 , but it might also be true that they are being held back by the lack of resources and a focus on too narrow a task. The failure of NCLB is that it tries to manipulate the conditions within schools to make education a fail-safe activity when it isn't. A focus on a narrow range of outcomes, with standardised approaches to measuring them, and with negative consequences for schools that don't measure up, the so-called high-stakes testing mentality, leads to little room for error or, at least in the minds of many, it leaves little room for variation from the narrow outcomes to be assessed. It is possible that other important or valuable aspects of education of the whole person could be seen as taking time away from those aspects that are assessed, which would appear to increase error as presently measured. If a student is not successful on standardized tests, there is little else that a school can offer. 
The third finding is that the curriculum supported under NCLB has become narrow and focused and that the measurement of this narrow range of skills has become the single criterion upon which school success is judged, to the extent that many students leave school without the broader range of skills they need to live their lives well. Many argue that education has a broader purpose.

Education should prepare students for life. This includes stimulating their personal development, citizenship and readiness for the labour market. Assessing the extent to which these goals are accomplished is essential. (Luyten, et al. p. 253)

An "effective" U.S. school now is judged in very narrow ways and simply ignores what Bogotch and colleagues term "instrumental questions," such as "effective for what" and “effective for whom" (2007, p. 93). "Effectiveness for what? does not mean anything at all as long as it is not specified what it is that the teaching or schooling aims to achieve" (p. 99). There are also many ways in which effectiveness could be measured. Gorard (2011) makes the point:

There are also, of course, a number of differing ways of judging school performance. Schools could be evaluated in terms of financial efficiency, student attendance, student enjoyment of education, future student participation in education, student aspiration, [and] preparation for citizenship and so on (p. 745-746).

One of the difficulties facing school leaders is that decisions about what the aims of education should be are no longer within (or are not seen to be within) the province of local communities or the school leaders trying to serve them as best they can. This lack of discussion about the purpose of education seems to serve some groups better than others. Biesta (2009) argues "that the absence of explicit attention for the aims and ends of education is the effect of often implicit 
reliance on a particular 'common sense' view of what education is for. We have to bear in mind, however, that what appears as 'common sense' often serves the interests of some groups (much) better than those of others" (p. 37). He identifies what he calls the qualification function of education, where "the idea that what matters most is academic achievement in a small number of curricular domains, particularly language, science and mathematics” (p. 37). However, as school communities become increasingly diverse and more complex year by year, and where school leaders have to move from simple, through complicated, to complex problems (Patton, 2008), from structured to unstructured ones (Leithwood \& Steinbach, 1995) or from tame, to critical to wicked ones (Grint, 2005), then this common sense approach serves fewer and fewer people.

The fourth finding is that increasingly the power to make decisions locally, the foundation upon which U.S. democracy is built, is being eroded as decisions that shape how education is implemented are taken out of the hands of schools and school districts and given to politicians. This is a shift from past practices where school boards were very active in determining what happened in schools. Now, important decisions are made at the Federal or State levels, as are judgments about the level of performance of individual schools. It could be argued that perhaps local communities were not good at making judgments about what the role of education should be, or how performance is judged, but it seems the balance has moved very strongly from one side to the other. School leaders were once trusted to support their communities to make these judgments, but now this seems not to be the case.

It needs to be said that concerns expressed by the Voices 3 data are echoed by school leaders in other parts of the world as well. MacBeath and Townsend's (2011) research findings contain many quotes about the difficulties facing school leaders in a number of countries where the range of expectations for what should be achieved is constrained by the way in which school 
success is judged. In South Africa "there is little wriggle room for headteachers who are directly in the firing line of political pressure" (p. 1241) and in China principals describe their work lives as "uncomfortable, increasingly uncertain and fraught with tensions" (Qian \& Walker, 2011, p. 210). In the U.S., there are "miserable" and "frustrated" principals (Fink, 2011, p. 587), one of whom commented "Everything has a number to it. I have to make sure all those numbers are increasing, that the trend is upward on all pieces of data except for things like suspension rates" (Reitzug \& West, 2011, p. 169). In Australia, "the ability to focus on leading learning and, on the other hand, the ability to manage the multiple accountability demands determined by the policy environment is considered a significant challenge in the Australian quest to prepare and support school leaders more effectively" (Thomas \& Watson, 2011, p. 1242).

The source of tension might be considered as the difference between "sollen" (duty) and “woollen" (aspiration), terms used by Schley and Schratz (2011) to depict the leadership dilemma in Austria where government interventions cause an overload problem "by piling disconnected policies one upon one another, leading to a sense of confusion and uncertainty" (p. 268). This is brought about when "close interconnections between education and economic growth are apparent," (Dimmock \& Goh, 2011, p. 226) thus leading school leaders to be "forced to engage in both front-stage and back-stage performances when they play out their role of leaders for learning" (Qian \& Walker, 2011, p. 210). There is much that the school leaders in the Voices 3 project would like to do with and for their students, but what they CAN do for students is constrained by the narrow measure of success determined by those outside the school.

The fifth finding is that there is a pervasively negative environment in which school leaders have to work. Townsend, et al., (in preparation) suggest that we ask ourselves the question "Do we trust our school leaders and teachers to do the job of educating our students or 
not?" Gronn (2011) argues it is difficult to build trusting relationships at the local level when "external circumstances are ill-conducive to the genesis and maintenance of trust" (p. 100).Townsend, et al., (in preparation) argued "The use of Blue Ribbon schools (U.S. Department of Education, 2012) at one end of the spectrum, and the reconstitution of schools (Rice \& Malen, 2003) at the other end, suggests that educational achievement is a transaction" rather than an exchange between people.

Yet much of what happens in schools today is completely out of school leaders' hands. Imig et al. (2011) reported: "Classrooms experienced sharply increased class sizes and reductions in supporting staff and aides. School calendars were shortened and more than a hundred thousand teachers were "pink slipped" or told their contracts would not be renewed for the 2011-12 school year" (p. 402). Clearly all of these changes would impact poorly on student learning, but none are in the control of the school leader.

O'Neill (2002) argued that the erosion of professional trust is directly related to illconceived accountability measures. "I think we may undermine professional performance and standards in public life by excessive regulation, and that we may condone and even encourage deception in our zeal for transparency... We need more intelligent forms of accountability". This lack of trust, matched with zealous accountability measures, has led to an environment where many teachers (Shockley et al., 2006) and school leaders (Lovely, 2004) choose not to continue. The cost involved in replacing them is enormous (Shockley et al., 2006).

\section{Conclusions}

We acknowledge that in the interim period between 2006 and now, there have been substantial changes, both in policy and leadership practice. Weldon (2011, online, para. 1) argued the cost and stress associated with complying with NCLB has led some states (for 
example, South Dakota, Idaho, Kentucky) to refuse to comply with some aspects of the law, risking the loss of federal funds. He pondered "Whether the 'rebellion' turns out to be the action of two or three 'renegade' states, or the beginning of a much wider revolution is something many education policymakers are watching closely." By June, 2012, 26 states were "now relieved from meeting the lofty — and controversial — goal of making all students proficient in reading and mathematics by 2014" (Rich, 2012, para. 2). That more than half of the states in the country had chosen to withdraw from the program suggests that there is a level of concern about how it was implemented.

Also we have seen the further development of leadership approaches such as transformational leadership (Leithwood \& Janzti, 2000), shared (Lambert 2002) or distributed leadership (Cox, Pearce, \& Perry, 2003; Gronn, 2002; Spillane, Halverson, and Diamond 2001, 2004), which support more than simply a hierarchical approach. Perhaps most important, is the need for research into other models of school leadership, ones that promote the perspective that the principal is one of many leaders required if schools are expected to do their job well. Consideration might be given to leadership for learning, with its five underlying principles of a focus on learning; establishing conditions for learning; dialogue; sharing leadership; and sharing accountability (Townsend \& MacBeath, 2012, pp. 9-10). In fact both Hallinger and Murphy, who began using the term instructional leadership in the mid-1980s, have both recently, and separately, used the term leadership for learning in their writing. Murphy et al., (2007) argued: This type of leadership can best be labeled "leadership for learning," "instructionally focused leadership" or "leadership for school improvement." The touchstones for this type of leadership include the ability of leaders (a) to stay consistently focused on the right stuff - the core technology of schooling, or learning, teaching, curriculum and 
assessment and (b) to make all the other dimensions of schooling (e.g. administration, organization, finance) work in the service of a more robust core technology and improved student learning (p. 179).

...which came with a new list of things for school leaders to undertake:

The knowledge base of leadership for learning is captured under eight major dimensions: vision for learning, instructional program, curricular program, assessment program, communities of learning, resource acquisition and use, organizational culture, and advocacy. (Murphy et al, 2007, p. 179)

However, if we ask what is different between the 1985 list (Hallinger \& Murphy) and the 2007 list (Murphy et al.) we find the answer is "not a lot". Vision for learning might be considered as the school's mission; the instructional program, curricular program and assessment program are subsumed under managing the instructional program; communities of learning, organizational culture and advocacy together might be considered as promoting a positive school learning climate; so perhaps the only thing that is different is resource acquisition and use. Perhaps this has occurred more because of changes in school system policies than anything to do with what leaders would like to be doing. Now, because schools no longer have the resources they once enjoyed, supplied by state and local taxes, they have to establish ways of garnering resources themselves.

Hallinger and Heck (2010), too, use the term "leadership for learning." In recent years, the phrase "leadership for learning" has gained international currency (MacBeath et al., 2008; Robinson et al., 2008). In our view, this approach to school leadership represents a blend of two earlier leadership conceptualizations: instructional leadership and transformational leadership. (Hallinger \& Heck, 2010, p. 657) 
But this definition of leadership for learning still focuses on the leader as the main architect of school success.

Leadership for learning, as we interpret it, goes beyond transformational leadership in that expands leadership options beyond the leader, and it goes beyond distributed leadership because leadership needs to expand not only within the school, but at both district and system level as well. It could be argued that leadership for learning is designed to create learning at all levels within the system, student learning, teacher learning, organisational learning and leadership learning, all at once. The task is to look at where the school, or school system is now, make some decisions about where it wants to be and then enable these to: "...unfold from within the fabric of school life, reflect and respond to the conditions that prevail in the school, and be authentically connected to the daily work of teachers and students" (Mitchell \& Sackney, 2011, p. 977). It could be further argued that focusing on learning for all, student learning, teacher learning, leader learning and system learning, rather than focusing only on specific outcomes, is the best way of actually improving those outcomes anyway, because it relies on interacting comprehensively with one's environment rather than simply remembering discrete elements of it. Within such a leadership style teaching for deep understanding (Leithwood et al., 2006) becomes the norm, rather than the exception.

To adopt the Leadership for Learning philosophy, we have to embrace dialogue. We need dialogue between educational leadership professors across countries, so that successful and promising practices around the world can be shared. Then we need dialogue between academics and policy makers to enable these successful practices to be embedded in local systems. Finally we need dialogue between politicians and system administrators, between school boards and superintendents, between school leaders, teachers and parents, and between teachers and 
students. Dialogue involves a power shift, as it does not encourage hierarchies. So we need to stop telling people what to do and start asking questions, questions like "What is the purpose of school in a modern, technological and diverse world?" and "How can we redefine being successful at school so that more than one third of students can be so?" This is not to reject the need to consider the task, but accepts that tasks are only completed if people are aligned with them. It is at the interchange between one way of looking at schools and the other, where task and people become equally important, that the interesting developments, especially related to school leadership in the future, might lie.

\section{References}

Abrams, L. M., Pedulla, J. J., \& Madaus, G. F. (2003). Views from the classroom: Teachers' opinions of statewide testing programs. Theory Into Practice, 42(1), 18-29.

Acker-Hocevar, M. A., Ballenger, J., Place, A. W., \& Ivory, G. (2012). Snapshots of school leadership in the $21^{\text {st }}$ century: Perils and promises of leading for social justice, school improvement, and democratic community (The UCEA voices from the field project), Charlotte, NC: Information Age Press.

Alsbury, T., \& Whitaker, K. (2012). Pressure of outside forces, stress, and finding balance. In Acker-Hocevar, M. A., Ballenger, J., Place, A. W., \& Ivory, G. (eds.) Snapshots of school leadership in the 21st century: Perils and promises of leading for social justice, school improvement, and democratic community (The UCEA Voices from the field project), 169187. Charlotte, NC: Information Age Press. 
Barber, M., Whelan, F., \& Clark, M. (2010). Capturing the leadership premium: How the world's top school systems are building leadership capacity for the future. Boston: McKinsey \& Company

Biesta, G. (2009). Good education in an age of measurement: on the need to reconnect with the question of purpose in education. Educational Assessment, Evaluation and Accountability 21, $33-46$

Bogotch, I., Miron, L., \& Biesta, G. (2007). Effective for What; Effective for Whom? Two Questions SESI Should Not Ignore. In Townsend, T. (ed.) International Handbook of School Effectiveness and Improvement, 93-110, New York, NY: Springer.

California Department of Education (2012). Standardized Testing and Reporting (STAR). Retrieved from http://www.cde.ca.gov/ta/tg/sr/

CBEST (2012). California Education Basic Skills Test: CBEST Practice Test. Retrieved from http://www.cbest.nesinc.com/PDFs/CA_OPT_Reading.pdf

Chase, G., \& Kane, M. (1983). The principal as instructional leader: How much more time before we act? Denver, CO: Education Commission of the States.

Clinch, R. (2001). Secret kids’ business. Melbourne: Hawker-Brownlow.

Coleman, J. S., Campbell, E., Hobson, C., Mc Partland, J., Mood, A., Weinfield, F., \& York, R. (1966). Equality of Educational Opportunity, Washington, D.C., U.S. Govt Printing Office. Cox, J., Pearce, C., \& Perry, M., (2003). Toward a model of shared leadership and distributed influence in the innovation process: How shared leadership can enhance new product development team dynamics and effectiveness. In C. L. Pearce \& J. A. Conger (eds.), Shared leadership: Reframing the hows and whys. Thousand Oaks, CA: Sage. 
Darling-Hammond, L., \& Rustique-Forrester, E. (2005). The Consequences of Student Testing for Teaching and Teacher Quality. In Herman, J., and Haertel, E. (eds.) The Uses and Misuses of Data in Accountability Testing. The 104th Yearbook of the National Society for the Study of Education, Part II, 289-319. Malden, MA: Blackwell Publishing Dimmock, C., \& Goh, J. (2011). Transforming Singapore Schools: The Economic Imperative, Government Policy and School Principalship. In Townsend, T., and MacBeath, J. (eds.) The International Handbook of Leadership for Learning, 225-242, New York, NY: Springer.

DiPaola, M., Acker-Hocevar, M., Davis, J. E., Grogan, M., \& Ivory, G. (2002). Leadership perspectives of the superintendency: Perceptions, reflections, and observations from the field. University Council for Educational Administration, November 2002.

Edmonds, R. (1979). Effective schools for the urban poor. Educational Leadership, 37, 15-27.

Elmore, R. F. (2003). A plea for strong practice. Educational Leadership, 61(3), 6-10.

Elmore, R. (2007). Educational Improvement in Victoria. Melbourne, Victoria: Office for Government School Education, Department of Education.

Fink, D. (2011). The Succession Challenge: Warm Bodies or Leaders of Learning? In Townsend, T. and MacBeath, J. (eds.). The International Handbook on Leadership for Learning, 589602, Dordrecht, Springer.

FLDOE (2012a). Florida's K-12 Statewide Assessment Program. retrieved from http://fcat.fldoe.org/

FLDOE (2012b). Grade 10 FCAT Reading Sample Questions. Retrieved from http://fcat.fldoe.org/pdf/sample/0910/reading/FL517300_10_Rdg_TB_WT_r2g.pdf

Fullan, M. (2005). Turnaround leadership. The Educational Forum, 69, 174-18 
Fuller, E. (2006). Teacher and Parent Perceptions of the Texas Assessment of Knowledge and Skills. Association of Texas Professional Educators

Gates, B. (2011). How state budgets are breaking US schools. Retrieved from http://www.ted.com/talks/bill_gates_how_state_budgets_are_breaking_us_schools.html

Gorard, S. (2011). Serious doubts about school effectiveness. British Educational Research Journal, 36, 5, $745-766$

Great Schools (2012). No Child Left Behind (NCLB) Requirements for Schools. Retrieved from http://www.greatschools.org/definitions/nclb/nclb.html

Grint, K. (2005). Problems, problems, problems: The social construction of 'leadership'. Human Relations, 58, 11, 1467-1494.

Gronn, P. 2002. Distributed leadership as a unit of analysis. Leadership Quarterly 13: 423-51.

Gronn, P. (2003). The new work of educational leaders: Changing leadership practice in an era of school reform. London: Paul Chapman.

Gronn, P. (2011). Risk, Trust and Leadership. In Sugrue, C. and Solbrekke, T. Professional Responsibility: New Horizons of Praxis. Routledge: London and New York

Gross, S. J., \& Shapiro, J. P. (2005). Our new era requires a new DEEL: Towards democratic ethical educational leadership. UCEA Review, 48(3), 1-4.

Hallinger, P., \& Heck, R. H. (2010). Leadership for Learning: Does collaborative leadership make a difference in school improvement? Educational Management Administration \& Leadership 38, 654-678.

Hallinger, P., \& Heck, R. H. (2011). Collaborative leadership and school improvement: Understanding the impact on school capacity and student Learning. In Townsend, T., and 
MacBeath, J. (eds.) The International Handbook of Leadership for Learning, 1241-1259, New York, NY: Springer.

Hallinger, P., \& Murphy, J. (1985). Assessing the instructional management behavior of principals. The Elementary School Journal, 86(2), 217-248.

Hargreaves, D. (2009). Personalising learning: Next steps in working laterally. Retrieved from http://www.ssat-inet.net/pdf/Next\%20steps\%20in\%20working\%20laterally\%20\%20Chapter\%201.pdf

Hattie, J. (2008). Visible Learning: A synthesis of over 800 meta-analyses relating to achievement. London: Routledge.

Imig, D., Wiseman, D., \&Imig, S. (2011). Teacher Education in the United States, 2011. Journal of Education for Teaching, 37, 4, 399-408

Jencks, C.S., Smith, M., Ackland, H., Bane, M., Cohen, D., Gintis, H., Heyns, B., \& Michelson, S. (1972). Inequality: A reassessment of the effect of family and schooling in American. New York, NY: Basic Books.

Kew, K., Ivory, G., Muñiz, M., \& Quiz, F. (2012). No Child Left Behind as School Reform: Intended and Unintended Consequences. In Acker-Hocevar, M. A., Ballenger, J., Place, A. W. \& Ivory, G. Snapshots of school leadership in the 21 st century: Perils and promises of leading for social justice, school improvement, and democratic community (The UCEA Voices from the field project), 13-30, Charlotte, NC: Information Age Press.

Kochan, F. K.., Jackson, B. L., \& Duke, D. L. (Eds.) (1999). A thousand voices from the firing line: A study of educational leaders, their jobs, their preparation, and the problems they face. Columbia, MO: University Council for Educational Administration.

Lambert, L. 2002. A framework for shared leadership. Educational Leadership 59, no. 8: 37-40. 
Leithwood, K., \& Steinbach, R. (1992). Improving the Problem Solving Expertise of School Administrators: Theory and Practice. Education and Urban Society, 24, 317-345

Leithwood, K., \& D. Janzti. (2000). The effects of transformational leadership on organisational conditions and student engagement with school. Journal of Educational Administration, 38, $2,112-29$.

Leithwood, K., McAdie, P., Bascia, N., \& Rodrigue, A. (2006). Teaching for Deep Understanding: What Every Educator Should Know. New York, Corwin.

Little, D. (2012). The Glass Is Half Fullan (again). Retrieved from http://www.thelittleeducationreport.com/TheGlass.html Item 5, paragraph 16

Lovely, S. (2004) Staffing the Principalship: Finding, Coaching and Mentoring School Leaders Washington D.C.: ASCD.

Luyten, H., Visscher, A., \& Witziers, B (2005). School Effectiveness Research: From a review of the criticism to recommendations for further development, School Effectiveness and School Improvement, 16, 3, 249-279

MacBeath, J., \& Townsend, T. (2011). 'Thinking and Acting Both Locally and Globally: What Do We Know Now and How Do We Continue to Improve?' In Townsend, T., and MacBeath, J. (eds.) The International Handbook of Leadership for Learning, 1241-1259. New York, NY: Springer.

Madden, D. B. (2008). Middle School Educators' Perspectives of Changes in Teaching Practices Caused by Implementation of the FCAT Science. Electronic Theses, Treatises and Dissertations. Paper 2805. 
Mitchell, C., \& Sackney, L. (2011). Building and Leading Within Learning Ecologies. In Townsend, T., and MacBeath, J. (eds.) The International Handbook of Leadership for Learning, 993-1012. New York: Springer.

Murakami-Ramalho, E. \& Mariela A. Rodríguez, M. (2012). School Superintendents and Principals Meeting the Academic Needs of All Learners. In Acker-Hocevar, M. A., Ballenger, J., Place, A. W., \& Ivory, G. Snapshots of school leadership in the 21st century: Perils and promises of leading for social justice, school improvement, and democratic community (The UCEA Voices from the field project), 55-74. Charlotte, NC: Information Age Press.

Murphy, J. (2002). Reculturing the profession of educational leadership: New blueprints. Educational Administration Quarterly, 38, 176-191.

Murphy, J., Elliott, S., Goldring, E., \& Porter, A. (2007). Leadership for learning: a researchbased model and taxonomy of behaviors, School Leadership \& Management, 27:2, 179-201

National Assessment of Educational Progress (NAEP), (2009). NAEP 2009 Year in Review, Washington DC: National Center for Educational Statistics.

No Child Left Behind Act of 2001, Pub. L. No. 107-110 (2002). Retrieved from: http://www.nochildleftbehind.com/NCLB-full-text.pdf

NYSED (2012). 2010 English Language Arts Grade 4 Test. Office of State Assessment. Retrieved from http://www.nysedregents.org/Grade4/EnglishLanguageArts/home.html O’ Neill, N. (2002). A Question of Trust, Reith Lecture, Radio 4. Retrieved from http://www.bbc.co.uk/radio4/reith2002/ 
Palmer, D., \& Lynch, A.W. (2008) A bilingual education for a monolingual test? The pressure to prepare for TAKS and its influence on choices for language of instruction in Texas elementary bilingual classrooms. Language Policy, 7, 217-235

Patton, M. Q. (2008). Utilization-focused evaluation (4 ${ }^{\text {th }}$ Ed.). Los Angeles, CA: Sage. Pearson (2012). Practice Tests for the Texas Academic Skills Program Reading Test. Pearson Publishing. Retrieved from http://wps.ablongman.com/long_henry_sr_1/12/3146/805617.cw/index.html

Pedwell, L. Levin, B., Pervin, B., Gallagher, M.J., Connor, M., \& Beck, H. (2011). Building Leadership Capacity Across 5,000 Schools. In Townsend, T., and MacBeath, J. (eds.) The International Handbook of Leadership for Learning, 601-616. New York: Springer.

Peterson P., \& West, M. (2003). No child left behind: The politics and practice of school accountability. Washington DC: Brookings Institution.

Qian, H., \& Walker, A. (2011). Leadership for learning in China: The political and policy context. In Townsend, T., and MacBeath, J. (eds.) The International Handbook of Leadership for Learning, 209-224. New York: Springer.

Ravitch, D., \& Chubb, J. (2009, Summer). The future of No Child Left Behind. Education Week, $9(3), 1$

Reitzug, U., \& West, D. (2011). A developmental framework for instructional leadership. In Townsend, T., and MacBeath, J. (eds.) The International Handbook of Leadership for Learning, 169-188. New York: Springer.

Rice, J. K., \& Malen, B. (2003). The human costs of education reform: The case of school reconstitution, Educational Administration Quarterly, 39, 5, 635-666. 
Rich, M. (2012). 'No Child' Law Whittled Down by White House. New York Times, July 6, 2012.

Schley, W. \& Schratz, M. (2011). Developing Leaders, Building Networks, Changing Schools Through System Leadership. In Townsend, T., and MacBeath, J. (eds.) The International Handbook of Leadership for Learning, 267-296. New York: Springer.

Shockley, R., Guglielmino, P., \& Watlington, E. (2006). The Costs of Teacher Attrition. Presented at the International Congress for School Effectiveness and Improvement, Fort Lauderdale, Florida. Retrieved from http://www.leadership.fau.edu/ICSEI2006/Papers/Shockley\%20Guglielmino\%20and\%20W atlington.pdf.

Spillane, J.P., R. Halverson, and J.B. Diamond. (2001). Investigating school leadership practice: A distributed perspective. Educational Researcher 30: 23-8.

Spillane, J.P., R. Halverson, and J.B. Diamond. (2004). Towards a theory of leadership practice: A distributed perspective. Journal of Curriculum Studies 36: 3-34

Taylor, R., \& Touchton, D., (2005). Voices from the Field: What Principals Say About Their Work. Journal of Scholarship and Practice, 1 (4), 13-15.

Texas Education Agency (2009). Growth Model Pilot Application for Adequately Yearly Progress Determinations under the NCLB. The U. S. Department of Education. Retrieved from www2.ed.gov/admins/lead/account/growthmodel/tx/txproposrpt12122009.pdf.

Thomas, S., \& Watson, L. (2011). Quality and Accountability: Policy Tensions for Australian School Leaders. In Townsend, T., and MacBeath, J. (eds.) The International Handbook of Leadership for Learning, 189-208. New York: Springer. 
Townsend, T., \& MacBeath, J. (2012). Instructional Leadership and Leadership for Learning: Two sides of the same coin? Paper presented at the International Congress for School Effectiveness and Improvement conference, Malmo, Sweden, January 2012.

Townsend, T., Ivory, G., Acker-Hocevar, M., Ballenger, J., \& Place, A. W. (in preparation). School Leadership Challenges Under No Child Left Behind: Lessons from UCEA's Project. US Census Bureau (2012). School Enrolment: CPS October 2010 - Detailed Tables. Retrieved from http://www.census.gov/hhes/school/data/cps/2010/tables.html last downloaded on $\underline{09 / 24 / 2012}$

US Department of Education (2012). National Blue Ribbon Schools Program. Retrieved from http://www2.ed.gov/programs/nclbbrs/index.html (last downloaded October 15, 2012)

Weber, G. (1971). Inner City Children Can Be Taught to Read: Four Successful Schools, Washington, D.C.: Council for Basic Education.

Weldon, T. (2011). States rejecting NCLB Rules, Going it alone. Retrieved from http://knowledgecenter.csg.org/drupal/content/states-rejecting-nclb-rules-going-it-alone Winerip, M. (2012). Backtracking on Florida Exams Flunked by Many, Even an Educator. New York Times, June 10, 2102, para 20. Retrieved from http://www.nytimes.com/2012/06/11/education/florida-backtracks-on-standardized-statetests.html?adxnnl=1\&pagewanted=all\&adxnnlx=1351955343$\underline{\text { hwfPqO9CmQj8xiVTU/pMmA\&_r=0 }}$ 